\title{
Genetic parameters estimation and breeding values prediction for linear described traits in the Old Kladruber horse*
}

\author{
L. Vostrý ${ }^{1,2,3}$, J. Přibyl ${ }^{2,1}$, K. Mach ${ }^{1}$ and I. Majzlík ${ }^{1}$ \\ ${ }^{1}$ Czech University of Life Science, Faculty of Agrobiology, Food and Natural Resources \\ Prague, Kamýcká 129, 16521 Prague 6-Suchdol, Czech Republic, \\ ${ }^{2}$ Institute of Animal Science \\ Přátelství 815, 10400 Prague-Uhřiněves, Czech Republic
}

(Received 29 November 2010; revised version 21 July; accepted 4 August 2011)

\begin{abstract}
Genetic parameters estimates and breeding values for 36 conformation traits repeatedly observed over 16 years with a linear description of the type were evaluated for 977 Old Kladruber horses. The genetic parameters were estimated using the restricted maximum likelihood method with a multitrait animal model. The model included the following fixed effects: breed variant, herd, breed variant $\times$ herd interaction, sex, age at description, and year of description. Random effects, such as the individual and permanent environmental effect of the animal, were also included. The heritability estimates for traits were between 0.04 and 0.65 , while the values of genetic correlation were in the interval of -0.68 to 0.96 . Standard deviations of the breeding values of conformation traits were between 0.14 and 1.03 . The breeding values will be used for more effective selection of typical conformation traits in the Old Kladruber horse.
\end{abstract}

KEY WORDS: horse, Kladruber, linear description, heritability, correlation, REML

\section{INTRODUCTION}

The Old Kladruber horse is an original Czech breed. It has an important gene pool with unique characteristics and high cultural and historical value. The breed

\footnotetext{
* Supported by the Ministry of Education, Youth and Sports of the Czech Republic, Project No. MSM 6046070901, and by the Ministry of Agriculture of the Czech Republic, Project No. MZE 0002701404

${ }^{3}$ Corresponding author: e-mail: vostry@af.czu.cz
} 
is kept in the National Stud farms in herds of white and black horses and also by private breeders. The Old Kladruber horse belongs among the endangered breeds because the number of mares is below 1.000 heads. This breed has been raised continuously in the territory of the Czech Republic for more than 400 years. Initially, the continuous import of Old Spanish horses from dependable European farms, in particular those of Italy, took place in order to refresh the genetic base of the stock. However, the Old Spanish horse began to lose popularity at the turn of the $18^{\text {th }}$ century, and subsequently the stocks of such animals in Europe largely disappeared. Since then, the breeding of the horses of the Italo-Spanish type has remained exclusive to Kladruby, i.e. without introducing new blood from other breeds. Since this horse was the only significant carrier of the ItaloSpanish bloodline, other than the Lipizzan or Andalusian horse, it has since been recognized as a separate breed called the Old Kladruber horse.

The population was closed in 1992 to prevent a further inflow of genes of related breeds. Currently, Old Kladruber horse in gray and black variety is a warmblood breed with a large frame of the heavy carriage horse type in which the typical baroque conformation has been preserved.

A linear description of type successfully is used in cattle since 1967 (Cassell et al., 1973) with very effective results. In this system the variability of conformation traits is described as the degree of development of this trait between its biological extremes on linear scale ranging, e.g., from 1 to 9 . Body conformation in the horse previously was evaluated by a scoring system, and then a linear description of conformation and type was introduced in nineties. The integral part of this system is the description of body conformation deviations from an optimum. Linear description of type and conformation in horse breeds were studied by Jakubec et al. $(1999,2007)$ in Old Kladruber horses, by Zechner et al. (2001) and Baban et al. (1998) in Lipizzan horses, and by Molina et al. (1999) in Andalusian horses.

The objective of this study was to estimate genetic parameters and breeding values with a linear description system used in Old Kladruber horses.

\section{MATERIAL AND METHODS}

\section{Descriptive characteristics of the data set}

The linear description of body conformation in the Old Kladruber horses was performed in accordance with the methodology of Jakubec et al. (1999). For the description of trait development, a linear scale from 1 to 9 was used (Table 1). The 36 traits were divided into the following 4 body parts: front, body, rear and limbs. 
Table 1. Description of the traits of the linear assessment system

\begin{tabular}{|c|c|c|c|c|}
\hline \multirow{2}{*}{ Number } & \multirow{2}{*}{ Trait } & \multicolumn{2}{|c|}{ Scale } & \multirow{2}{*}{ Optimum } \\
\hline & & 1 & 9 & \\
\hline \multicolumn{5}{|c|}{ Front } \\
\hline 1 & $\begin{array}{l}\text { height at withers (transformed } \\
\text { from measured values) (HW) }\end{array}$ & Low & High & 6 \\
\hline 2 & heftiness (HF) & Low & High & 6 \\
\hline 3 & head profile (HP) & Concave & Convex & 7 \\
\hline 4 & neck length (NL) & Short & Long & 6 \\
\hline 5 & neck tethering (NTe) & Low & High & 6 \\
\hline 6 & neck topside (NTo) & Concave & Convex & 6 \\
\hline 7 & withers length (WL) & Short & Long & 5 \\
\hline 8 & withers height (WH) & Low & High & 5 \\
\hline \multicolumn{5}{|c|}{ Body } \\
\hline 9 & topline length (TL ) & Short & Long & 6 \\
\hline 10 & topline vault (TV) & Weak & Straight & 6 \\
\hline 11 & loin length (LL) & Short & Long & 6 \\
\hline 12 & loin vault (LV) & Weak & Straight & 5 \\
\hline 13 & shoulder length (SL) & Short & Long & 5 \\
\hline 14 & shoulder slope (SS) & Straight & Sloping & 5 \\
\hline 15 & $\begin{array}{l}\text { chest girth (transformed } \\
\text { from measured values) (ChG) }\end{array}$ & Low & High & 6 \\
\hline 16 & chest length $(\mathrm{ChL})$ & Short & Long & 6 \\
\hline 17 & chest width (ChW) & Narrow & Broad & 5 \\
\hline 18 & chest depth (ChD) & Shallow & Deep & 6 \\
\hline 19 & breast width (BW) & Narrow & Broad & 5 \\
\hline \multicolumn{5}{|c|}{ Rear } \\
\hline 20 & croup length $(\mathrm{CrL})$ & Short & Long & 5 \\
\hline 21 & croup width (CrW) & Narrow & Broad & 5 \\
\hline 22 & croup shape $(\mathrm{CrS})$ & Sloping & Straight & 5 \\
\hline 23 & croup profile ( $\mathrm{CrP})$ & Roofy & Vaulty & 5 \\
\hline 24 & tail tethering (TT) & Low & High & 5 \\
\hline \multicolumn{5}{|c|}{ Limbs } \\
\hline 25 & forelimbs-front view (FIFV) & Narrow & Broad & 5 \\
\hline 26 & forelimbs-side view (FiSV) & Back at the knee & Over the knee & 4 \\
\hline 27 & foretoes side view (FtSV) & Sloping & Weak & 5 \\
\hline 28 & foretoe length (FtL) & Short & Long & 5 \\
\hline 29 & forehoof side view (FhSV) & Obtuse & Acute & 5 \\
\hline 30 & forehoof width (FhW) & Narrow & Broad & 5 \\
\hline 31 & forehoof size $(\mathrm{FhS})$ & Small & Large & 5 \\
\hline 32 & hind limbs-side view (HLSV) & Sickle hocked & Straight & 5 \\
\hline 33 & hind limbs-back view (HLBV) & Narrow & Broad & 5 \\
\hline 34 & fetlock from the side (FIFS) & Sloping & Weak & 5 \\
\hline 35 & length of the fetlock (LF) & Short & Long & 5 \\
\hline 36 & angle of hoof wall (AHW) & Obtuse & Acute & 5 \\
\hline
\end{tabular}


Data for the analyses were obtained from the Stud Book of the Old Kladruber horse (www.nhkladruby.cz). A normality test was used to demonstrate the normality of all descriptive traits (Shapiro-Wilk test; SAS, 2004).

The set for genetic parameters comprised 977 individuals (29\% stallions and $71 \%$ mares) over a period of 16 years (1990-2006). The offspring of 64 stallions ranged from 2 to 42 , with the average being 15 . The set included 1.369 observations - 585 horses had one observation and 392 horses had two observations. Repeated measurements were collected for assessment changes in the linear description of body conformation over time.

Due to the small number of individuals and the high number of traits, a repeatedmeasure single-trait and bivariate-trait model with permanent environmental effect was used to estimate the genetic variance and genetic covariance between all traits:

$$
\mathrm{y}=\mathrm{Xb}+\mathrm{Za}+\mathrm{Wpe}+\mathrm{e}
$$

where: $y$ - a vector of observations of the linear description; $b$ - a vector for fixed effects where the following fixed effects were included: Var - colour variant (white, black); ManagG - manager group (National stud, private herds); sexstallions and mares; AgeD - age at description $(1, \ldots, \geq 8$ year of age); YearD year of description $(\mathrm{m}=1990, \ldots, 2006) ; \mathrm{B} \times \mathrm{V}$ : breed $\times$ colour variant interaction $(\mathrm{n}=1, \ldots, 4)$; a - a vector of random additive genetic effects; pe - a vector of random permanent environmental effects; e - a vector of random errors; X, Z and $\mathrm{W}$ - incidence matrices associated with $\mathrm{b}, \mathrm{u}$ and pe, respectively. The expectation of $\mathrm{y}$ depends only on $\mathrm{Xb}$ because the other terms are random.

$$
\mathrm{E}(\mathrm{y})=\mathrm{Xb}
$$

Assumptions on the variance-covariance of the random components were:

$$
\operatorname{Var}\left[\begin{array}{c}
a \\
p e \\
e
\end{array}\right]=\left[\begin{array}{ccc}
A \sigma_{a}^{2} & 0 & 0 \\
0 & I \sigma_{p e}^{2} & 0 \\
0 & 0 & I \sigma_{e}^{2}
\end{array}\right]
$$

where: $\sigma_{\mathrm{a}}{ }^{2}, \sigma_{\mathrm{pe}}{ }^{2}$ and $\sigma_{\mathrm{e}}{ }^{2}$ - variances of additive genetic, permanent environmental, and temporary environmental effects (residual error), respectively; A - a relationship matrix composed of 1556 animals; I - an identity matrix representing 977 horses with observations.

The linear description of type traits in all individuals was performed by only one classifier. For this reason, the effect of the classifier was not included in the model equation. The linear description of conformation and type were completed 
regularly at the time of studbook entries or as a part of a performance test usually at the age of 4 years.

The pedigree set contained 5 generations of ancestors - 1.556 individuals. Unknown parents were included in one phantom parents group.

The computer package program VCE 5.1 (Kovač et al., 2002) was used to estimate the variance-covariance components and their standard errors.

To obtain positive definite variance-covariance matrices, the constructed genotypic and phenotypic variance-covariance matrices from the $\frac{N(N-1)}{2}$ bivariate analysis were adjusted by the weighted bending method (Jorjani et al., 2003). Phenotypic variance-covariance matrices were calculated based on genotype, permanent environment and residual variance-covariance matrices. Standard errors for the genetic correlation between the trait $\mathrm{x}$ and $\mathrm{y}\left[\sigma_{r G}(x, y)\right]$ were calculated using the estimated genetic correlation $\left(r_{G}\right)$, the estimated heritabilities of each trait $\left(h^{2}\right)$ and their respective SEs $\left(\sigma_{h}^{2}\right)$ (Falconer and Mackay, 1996):

$$
\sigma_{r G}(x, y)=\frac{1-r^{2}(x, y)}{\sqrt{2}} \sqrt{\frac{\sigma_{h_{x}^{2}} \sigma_{h_{y}^{2}}}{h_{x}^{2} h_{y}^{2}}}
$$

On the basis of the estimated variance and covariance components, other population-genetic parameters were derived: $\sigma^{2}$ - phenotypic variance $\left(\sigma^{2}{ }_{y}=\sigma^{2}{ }_{a}\right.$ $\left.+\sigma_{p e}^{2}+\sigma_{e}^{2}\right), h^{2}$ - direct heritability $\left(h^{2}=\sigma_{a}^{2} / \sigma_{y}^{2}\right)$ and $c^{2}$ - ratio of permanent environment $\left(c^{2}=\sigma_{p e}^{2} / \sigma^{2}\right)$.

\section{Prediction of breeding value}

Breeding values for traits of the linear description of the type were predicted by employing the BLUP multi-trait animal model (36 traits) and using the BLUPF90 programme (Misztal et al., 2002).

\section{RESULTS AND DISCUSSION}

\section{Descriptive characteristics}

Descriptive characteristics of the traits are shown in Table 2. The optimum value of each trait need not to correspond to the mean value of the score scale (value 5), but may deviate from it according to the breeding goal. Similar values were published by Jakubec et al. (2007). 
Table 2. Descriptive characteristics and estimations of variance components

\begin{tabular}{|c|c|c|c|c|c|c|c|c|c|}
\hline \multicolumn{2}{|l|}{ Trait $^{1}$} & \multirow[t]{2}{*}{ Mean } & \multirow[t]{2}{*}{$\mathrm{SD}$} & \multirow[t]{2}{*}{$\sigma_{a}^{2}$} & \multirow[t]{2}{*}{$\sigma_{p e}^{2}$} & \multirow[t]{2}{*}{$\sigma_{e}^{2}$} & \multirow[t]{2}{*}{$h^{2}$} & \multirow[t]{2}{*}{$s_{h}{ }^{2}$} & \multirow[t]{2}{*}{$c^{2}$} \\
\hline & Front & & & & & & & & \\
\hline HW & height at withers & 5.72 & 2.04 & 2.39 & 0.70 & 1.09 & 0.57 & 0.042 & 0.17 \\
\hline HF & heftiness & 5.87 & 1.55 & 1.19 & 0.23 & 1.00 & 0.49 & 0.046 & 0.10 \\
\hline HP & head profile & 5.20 & 1.59 & 1.78 & 0.24 & 0.71 & 0.65 & 0.038 & 0.09 \\
\hline NL & neck length & 5.12 & 1.16 & 0.15 & 0.01 & 1.17 & 0.11 & 0.025 & 0.005 \\
\hline $\mathrm{NTe}$ & neck tethering & 6.04 & 1.06 & 0.13 & 0.22 & 0.73 & 0.12 & 0.036 & 0.20 \\
\hline NTo & neck topside & 6.02 & 1.90 & 1.14 & 0.44 & 1.91 & 0.33 & 0.040 & 0.12 \\
\hline WL & wither length & 4.77 & 1.54 & 0.45 & 0.84 & 1.10 & 0.19 & 0.039 & 0.35 \\
\hline \multirow[t]{2}{*}{ WH } & wither height & 4.18 & 1.27 & 0.38 & 0.27 & 0.99 & 0.23 & 0.036 & 0.17 \\
\hline & Body & & & & & & & & \\
\hline TL & topline length & 5.70 & 1.24 & 0.45 & 0.28 & 0.87 & 0.28 & 0.044 & 0.18 \\
\hline TV & topline vault & 4.54 & 0.84 & 0.20 & 0.14 & 0.37 & 0.28 & 0.033 & 0.20 \\
\hline LL & loin length & 5.98 & 1.12 & 0.12 & 0.09 & 1.01 & 0.10 & 0.035 & 0.07 \\
\hline LV & loin vault & 4.31 & 1.11 & 0.18 & 0.15 & 0.86 & 0.15 & 0.034 & 0.13 \\
\hline SL & shoulder length & 4.49 & 0.89 & 0.05 & 0.001 & 0.64 & 0.07 & 0.023 & 0.001 \\
\hline SS & shoulder slope & 3.97 & 1.11 & 0.06 & 0.05 & 1.02 & 0.05 & 0.026 & 0.04 \\
\hline $\mathrm{ChG}$ & chest girl & 6.05 & 2.44 & 2.44 & 2.23 & 1.47 & 0.40 & 0.050 & 0.36 \\
\hline $\mathrm{ChL}$ & chest length & 6.01 & 1.09 & 0.25 & 0.08 & 0.76 & 0.23 & 0.038 & 0.07 \\
\hline $\mathrm{ChW}$ & chest width & 5.06 & 1.29 & 0.53 & 0.33 & 0.85 & 0.31 & 0.042 & 0.19 \\
\hline $\mathrm{ChD}$ & chest depth & 5.81 & 1.39 & 0.45 & 0.11 & 1.09 & 0.27 & 0.041 & 0.06 \\
\hline \multirow[t]{2}{*}{ BW } & breast width & 5.02 & 1.34 & 0.60 & 0.30 & 0.93 & 0.33 & 0.041 & 0.16 \\
\hline & Rear & & & & & & & & \\
\hline $\mathrm{CrL}$ & croup length & 4.12 & 1.03 & 0.09 & 0.08 & 0.91 & 0.08 & 0.028 & 0.08 \\
\hline $\mathrm{CrW}$ & croup width & 5.53 & 1.29 & 0.54 & 0.27 & 0.72 & 0.35 & 0.044 & 0.18 \\
\hline $\mathrm{CrS}$ & croup shape & 4.64 & 1.19 & 0.50 & 0.25 & 0.68 & 0.35 & 0.040 & 0.17 \\
\hline $\mathrm{CrP}$ & croup profile & 4.68 & 1.31 & 0.39 & 0.18 & 0.99 & 0.25 & 0.034 & 0.11 \\
\hline \multirow[t]{2}{*}{ TT } & tail tethering & 5.11 & 1.41 & 0.28 & 0.47 & 0.89 & 0.17 & 0.036 & 0.29 \\
\hline & Limbs & & & & & & & & \\
\hline FIFV & forelimbs - front view & 5.05 & 0.93 & 0.06 & 0.18 & 0.56 & 0.08 & 0.025 & 0.23 \\
\hline FiSV & forelimbs - side view & 3.85 & 1.71 & 0.28 & 0.20 & 2.39 & 0.10 & 0.026 & 0.07 \\
\hline $\mathrm{FtSv}$ & foretoe side view & 4.65 & 1.00 & 0.15 & 0.14 & 0.60 & 0.17 & 0.039 & 0.15 \\
\hline FtL & foretoe length & 4.64 & 1.06 & 0.19 & 0.00 & 0.71 & 0.21 & 0.031 & 0.001 \\
\hline FhSV & forehoof side view & 5.18 & 1.09 & 0.17 & 0.23 & 0.62 & 0.16 & 0.033 & 0.23 \\
\hline FhW & forehoof width & 4.90 & 1.02 & 0.44 & 0.06 & 0.58 & 0.41 & 0.039 & 0.05 \\
\hline FhS & forehoof size & 4.97 & 0.64 & 0.05 & 0.01 & 0.32 & 0.14 & 0.030 & 0.03 \\
\hline HLSV & hind limb side view & 4.35 & 1.01 & 0.04 & 0.34 & 0.51 & 0.05 & 0.031 & 0.39 \\
\hline HLBV & hind limb rear view & 4.81 & 0.85 & 0.03 & 0.11 & 0.54 & 0.04 & 0.028 & 0.16 \\
\hline FlFS & fetlock from the side & 4.88 & 0.82 & 0.04 & 0.09 & 0.47 & 0.06 & 0.030 & 0.15 \\
\hline LF & length of the fetlock & 4.32 & 1.00 & 0.18 & 0.10 & 0.63 & 0.20 & 0.039 & 0.11 \\
\hline AHW & angle of hoof wall & 5.18 & 0.97 & 0.17 & 0.09 & 0.58 & 0.20 & 0.033 & 0.11 \\
\hline
\end{tabular}

where: SD - standard deviation; $\sigma^{2}{ }_{a}$ - variance of direct genetic effect; $\sigma^{2}$ - variance of permanent environment of an individual; $\sigma_{e}^{2}{ }^{a}$-variance of residual error; $h^{2}$ - coefficient of direct heritability; $c^{2}$ - ratio of permanent environment $\left(c^{2}=\sigma_{t p}^{2} / \sigma_{y}^{2}\right) ; s_{h}{ }^{2}$ - standard error of heritability coefficient; ${ }^{1}$ see Table 1 


\section{Heritability and ratio of the permanent environment}

The estimates of variance components and heritabilities are presented in Table 2. The coefficients of heritability $\left(h^{2}\right)$ reached values higher than 0.40 in $14 \%$ of the traits, higher than 0.20 in $37 \%$ of the traits, and lower than 0.10 in $20 \%$ of the traits. The highest values of the coefficient were calculated for HP, HW and HF, while the lowest values for HLBV and HLSV. The lowest estimates of heritability were found for traits of the legs in comparison to the other trait groups. The low estimates for the heritabilities of the traits FIFV, SS, HLSV, HLBV and FIFS could be caused by the influence of factors other than additive genetics effects or by small variances of these traits. The values of standard errors of $h^{2}$, with the exception of FIFS, HLSV, FIFV and FiSV, indicated a statistical significance of $h^{2}$ estimation $(\mathrm{P}<0.05)$. These results showed that many linearly described traits were moderately heritable with small standard errors of $h^{2}$. The moderate heritabilities estimated for the traits of linear type description indicated that genetic improvement in these traits would be possible.

For some traits (e.g., HW, ChW, SL and others), similar values of heritability were estimated as in other horse breeds (Baban et al., 1998; Molina et al., 1999; Zechner et al., 2001; Fioretti et al., 2004). For other traits, the previously mentioned authors reported higher (NTe, HW and $\mathrm{CrL}$ ) or lower (ChG, $\mathrm{CrS}$ and $\mathrm{CrW})$ values of heritability.

\section{Genetic and phenotypic correlations}

The genetic correlations ranged between -0.53 and +0.96 with an average SE of 0.14 (Appendix I). The genetic correlation for many traits was low, between -0.30 and 0.30 , and rather close to zero, which indicates a virtual independence of these traits. Significant genetic correlations were estimated for $32 \%$ of the traits $(18 \%-\mathrm{P}<0.01$ and $14 \%-\mathrm{P}<0.05)$.

Low to medium genetic correlations were estimated for traits of the front group. For body traits, the frequency of high genetic correlations $(>0.5$, positive or negative) was higher compared to the traits of the front. Higher values of genetic correlation were also determined in the traits of the rear. Low to medium values of genetic correlations were determined in limb traits, similar to those of the traits of the front. In contrast to our results, Van Bergen and Van Arendonk (1993) reported lower values of genetic correlations. These differences may be caused by the fact that these characteristics were evaluated in different breeds and in different countries.

By comparing the genetic correlations between traits belonging to different trait groups, it was revealed that the majority of the characteristics were not or only weakly correlated. The highest genetic correlations between traits of different groups, with values exceeding the limit by \pm 0.30 , were found from 6 to $32 \%$. 


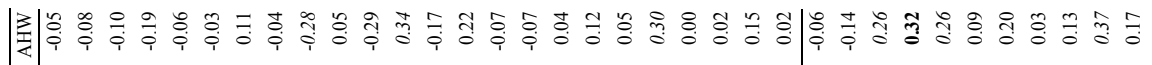
4 蒫

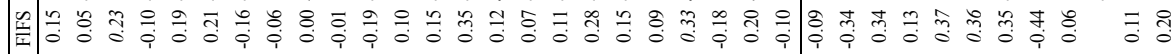

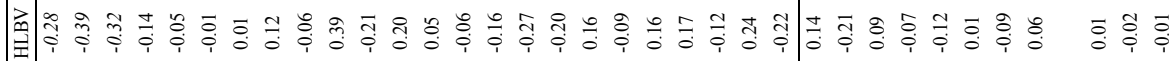

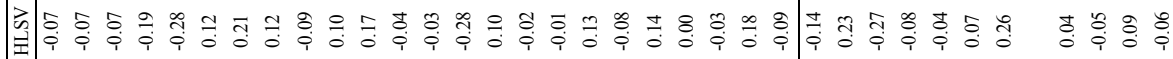

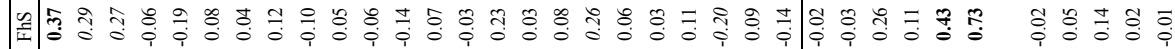

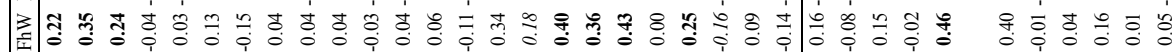

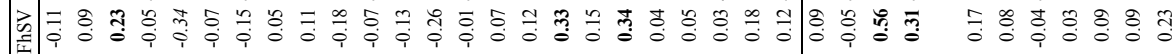

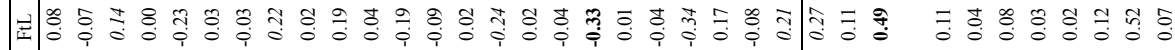

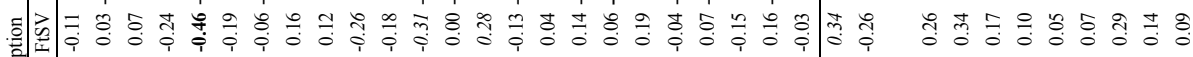

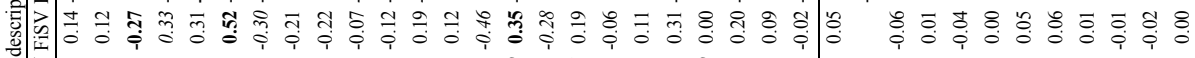

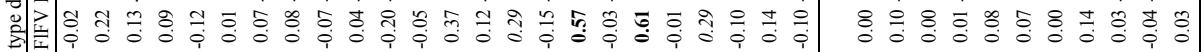

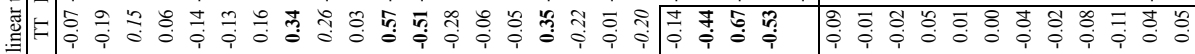

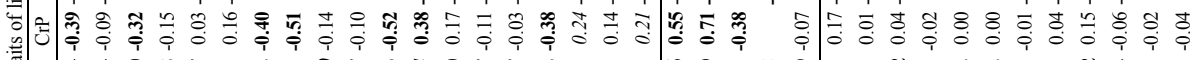

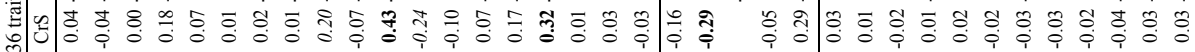

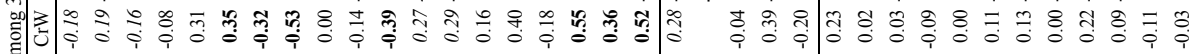

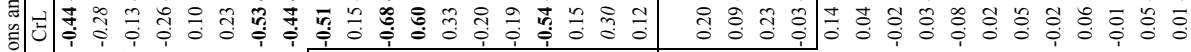

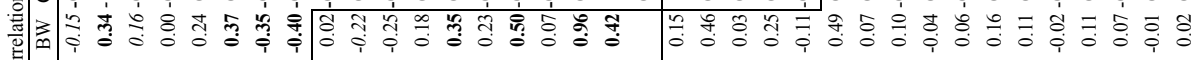

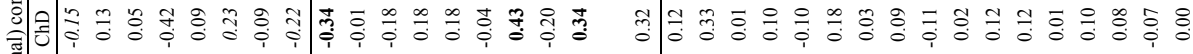

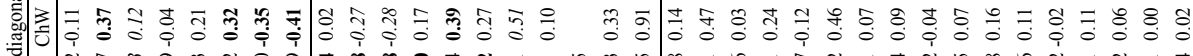

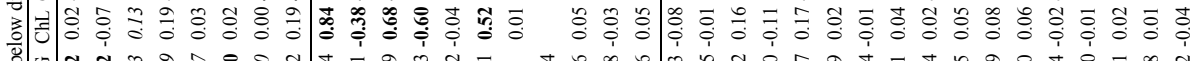

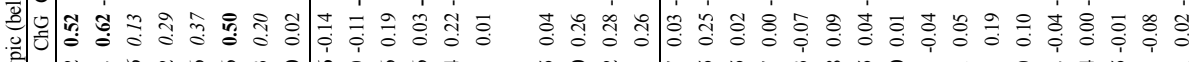

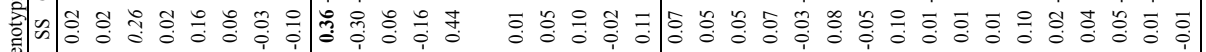
陆

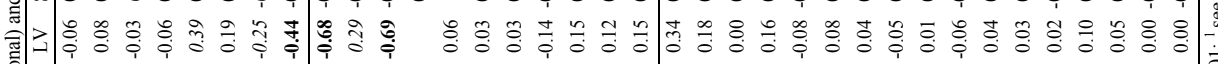

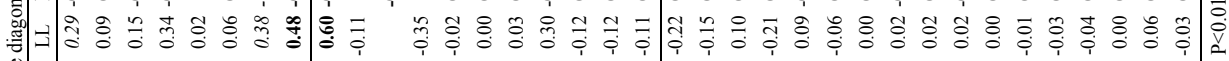

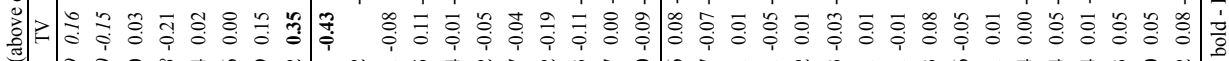
忽

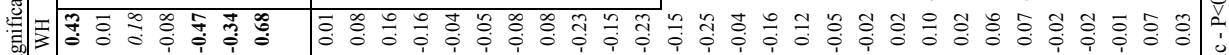
च⿹

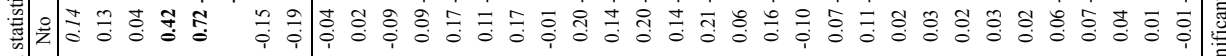

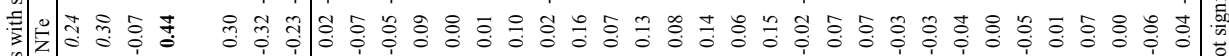

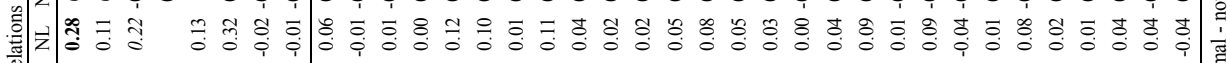

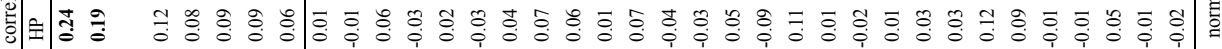

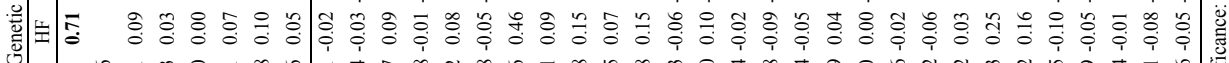

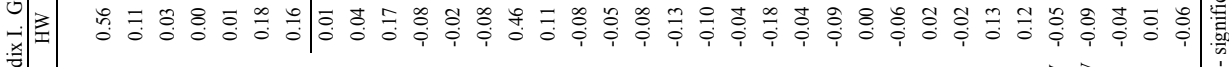

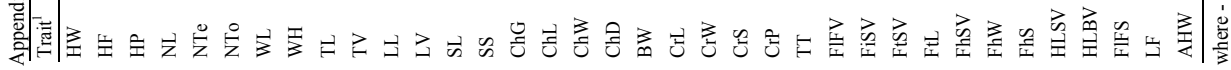


The estimated genetic correlations of traits within and between the 4 trait groups corresponded to the biological relationships between the traits studied. The high genetic correlation between the HW, HF, WL and WH showed the tendency of breeders to favour a bigger horse. The high genetic correlations that were high in this study suggest that it may not be necessary to include all traits of the linear description of type in a breeding programme that currently is in use.

Similar to genetic correlations, phenotypic correlations also have the highest values within the groups of body traits and lower values between the traits of different groups. A comparison of the values of $r_{G}$ and $r_{P}$ showed that the values of $r_{P}$ are closer to zero than are those of $r_{G}$. The low values of $r_{P}$ were caused by residual error, which have an opposite effect to that of the genetic factors, thus lowering the value of $r_{p}$. A decrease in the value of the phenotypic correlation relative to the genetic correlation was also described by Koenen et al. (1995), Molina et al. (1999) and Árnason and Sigurdsson (2004). However, these authors did not report such a marked decrease in the value of $r_{P}$ relative to $r_{G}$ as is reported here.

\section{Breeding values}

Before the introduction of a linear description of the type (Jakubec et al., 1999), conformation traits were classified on a subjective scale. With the traits linearly described, the traits are scored individually rather than in combination. The data recorded are an objective description of an animals conformation, based on a biological scale (Samoré et al., 1997). Moreover, analysis with a continuous scale and mixed-model evaluation are possible. Linear values of the animal and is relatives can be combined to predict the breeding value. Before the introduction of breeding values, animals were selected based on their phenotype value.

Table 3 shows the standard deviations, minimum and maximum of particular breeding values of linearly described traits. Optimal breeding values for most traits were zero, except for the head profile. The optimal breeding value for the head profile was 0.15 . To maintain the great variability and optimal body composition, the linear description of type can be useful for stabilization and corrective mating in particular cases.

Vostrý et al. (2011a) found average values of the inbreeding coefficient $\left(F_{X}\right)$ to be $7.3 \%$ in the Old Kladruber horse. Similar results were published by Vostrý et al. (2011b) on Czech cold-blooded breeds of horses.

The standard deviations of breeding values of linearly described traits ranged from 0.14 (HLBV) to 1.03 (ChG). The variability of breeding values depends among other values also from $h^{2}$. The lowest variances of breeding 
Table 3. Descriptive statistics of the estimation of breeding values

\begin{tabular}{|c|c|c|c|}
\hline Trait $^{1}$ & SD & Minimum & Maximum \\
\hline \multicolumn{4}{|l|}{ Front } \\
\hline HW & 1.00 & -3.46 & 3.22 \\
\hline $\mathrm{HF}$ & 0.71 & -2.17 & 2.76 \\
\hline $\mathrm{HP}$ & 0.87 & -2.69 & 3.18 \\
\hline NL & 0.26 & -0.90 & 1.06 \\
\hline $\mathrm{NTe}$ & 0.26 & -0.94 & 1.04 \\
\hline NTo & 0.62 & -2.25 & 2.20 \\
\hline WL & 0.41 & -1.37 & 1.37 \\
\hline WH & 0.37 & -1.31 & 1.46 \\
\hline \multicolumn{4}{|l|}{ Body } \\
\hline TL & 0.45 & -1.57 & 1.95 \\
\hline TV & 0.29 & -1.06 & 1.56 \\
\hline LL & 0.26 & -0.90 & 1.21 \\
\hline LV & 0.27 & -0.94 & 1.01 \\
\hline SL & 0.15 & -0.50 & 0.62 \\
\hline SS & 0.18 & -0.51 & 0.73 \\
\hline $\mathrm{ChG}$ & 1.03 & -3.09 & 3.33 \\
\hline $\mathrm{ChL}$ & 0.36 & -1.13 & 1.64 \\
\hline $\mathrm{ChW}$ & 0.45 & -1.41 & 1.73 \\
\hline $\mathrm{ChD}$ & 0.41 & -1.62 & 1.67 \\
\hline BW & 0.46 & -1.47 & 2.02 \\
\hline \multicolumn{4}{|l|}{ Rear } \\
\hline $\mathrm{CrL}$ & 0.21 & -0.72 & 0.79 \\
\hline $\mathrm{CrW}$ & 0.45 & -1.20 & 2.67 \\
\hline $\mathrm{CrS}$ & 0.42 & -2.31 & 1.67 \\
\hline $\mathrm{CrP}$ & 0.40 & -1.38 & 2.37 \\
\hline TT & 0.33 & -1.92 & 1.14 \\
\hline \multicolumn{4}{|l|}{ Limbs } \\
\hline FIFV & 0.22 & -0.67 & 0.93 \\
\hline FiSV & 0.36 & -1.08 & 1.10 \\
\hline FtSV & 0.22 & -1.05 & 0.92 \\
\hline $\mathrm{FtL}$ & 0.28 & -1.12 & 1.18 \\
\hline FhSV & 0.25 & -1.01 & 1.04 \\
\hline FhW & 0.37 & -0.97 & 1.83 \\
\hline FhS & 0.16 & -0.46 & 1.00 \\
\hline HLSV & 0.15 & -0.48 & 0.64 \\
\hline HLBV & 0.14 & -0.56 & 0.63 \\
\hline FIFS & 0.16 & -0.61 & 0.92 \\
\hline LF & 0.27 & -1.08 & 0.97 \\
\hline AHW & 0.25 & -0.77 & 1.04 \\
\hline
\end{tabular}

${ }^{1}$ see Table 1

values were calculated for traits with low $h^{2}$ value. values were calculated for traits with low $h^{2}$ values and the highest variances in traits with the highest $h^{2}$ value. The estimated maximum and minimum breeding values are consistent with the above results. In the trait $\mathrm{ChG}$, the high variance of breeding values 
was caused by the high genetic and phenotypic variability of this trait in the population. The breeding values will be used for effective selection of sires and dams to get correct conformation of heavy carriage horse in offsprings of the Old Kladruber horse.

\section{CONCLUSIONS}

Linear description of type trait is an indispensable in the breeding programmes of Old Kladrub horses to retain specific conformation traits in future generations. Linear description is an efficient tool to pursue a breeding objective with respect to conformation.

The results revealed that the traits of linear description of type in the Old Kladruber horses showed low to medium $h^{2}$ values. The only exception was the head profile $\left(h^{2}=0.65\right)$. The heritabilities and correlations estimated suggest that a genetic improvement of these traits is feasible.

\section{REFERENCES}

Árnason T., Sigurdsson A., 2004. International genetic evaluations of the Icelandic horse. In: Proceedings of $55^{\text {th }}$ Annual Meating of the EAAP, Bled (Slovenia), Paper HG5.3

Baban M., Rastija T., Caput P., Knezvc I., Stipic N., 1998. Estimation of heritability of Lipizzaner horses for morphological traits by means of various methods. Czech J. Anim. Sci. 43, 299-303

Cassell B.G., White J.M., Vinson W.E., Kliewer R.H., 1973. Genetic and phenotypic relationships among type traits in Holstein-Friesian cattle. J. Dairy Sci. 56, 1171-1177

Falconer D.S., Mackay T.F.C., 1996. Introduction into Quantitative Genetics. Longman House, Harlow, Essex, pp. 464

Fioretti M., Catalano A.L., Rosati A., Martuzzi F., 2005. Bardigiano horse selection: a genetic global index for linear type traits. Conservation genetic of endangered horse breeds. EAAP Publication, No. 116, 147-154

Jakubec V., Rejfková M., Volenec J., Majzlík I., Vostrý L., 2007. Linear type trait analysis in the varieties and studs of the Old Kladrub horse. Czech J. Anim. Sci. 52, 299-307

Jakubec V., Schlote W., Jelínek J., Scholz A., Záliš N., 1999. Linear type trait analysis in the genetic resource of the Old Kladrub horse. Arch. Tierzucht 42, 215-224

Jorjani H., Klei L., Emanuelin U., 2003. A simple method for weighted bending of genetic (co) variance matrix. J. Dairy Sci. 86, 677-679

Koenen E.P.C., Van Veldhuizen A.E., Brascamp E.W., 1995. Genetic parameters of linear scored conformation traits and their relation with dressage and show-jumping in the Dutch Warmblood Riding Horse population. Livest. Prod. Sci. 43, 85-94

Kovač M., Groeneveld E., García-Cortes L.A., 2002. VCE-5 A package for the estimation of dispersion parameters. In: $7^{\text {th }}$ WCGALP, Montpellier (France), CD-ROM Communication No. 28-06 
Misztal I., Tsuruta S., Strabel T., Auvray B., Druet T., Lee D.H., 2002. BLUPF90 and related programs (BGF90). In: $7^{\text {th }}$ WCGALP, Montpellier (France), CD-ROM Communication No. 28-07

Molina A., Valera M., Dos Santos R., Rodero A., 1999. Genetic parameters of morphofunctional traits in Andalusian horse. Livest. Prod. Sci. 60, 295-303

Samoré A.B., Pagnacco G., Miglior F., 1997. Genetic parameters and breeding values for linear type traits in the Hafliger horse. Livest. Prod. Sci. 52. 105-111

SAS, 2004. SAS/STAT ${ }^{\circledR} 9.1$ User's Guide. SAS Institute Inc. Cary, NC

Van Bergen H.M.M., Van Arendonk J.A.M., 1993. Genetic parameters for linear type traits in Shetland ponies. Livest. Prod. Sci. 36, 273-284

Vostrý L., Čapková Z., Přibyl J., Mach K., 2011b. Analysis of Czech Cold-Blooded horses - genetic parameters, breeding value and the influence of inbreeding depression on linear description traits. Czech J. Anim. Sci. 56, 217-230

Vostrý L., Kracíková O., Hofmanová B., Czerneková V., Kott T., Přibyl J., 2011a. Intra-line and inter-line genetic diversity in sire lines of the Old Kladruber horse based on microsatellite analysis of DNA. Czech J. Anim. Sci. 56, 163-175

Zechner P., Zohman F., Sölkner J., Bodi I., Habe F., Marti E., Brem G., 2001. Morphologic description of the Lipizzan horse population. Livest. Prod. Sci. 69, 163-177 